\title{
Note on a Conger with Abnormal Gonad.
}

By

A. E. Hefford, B.Sc.

With one Figure in the Text.

Among a sample of seven small Conger, from 58 to $77 \mathrm{~cm}$. in length, obtained from the Plymouth Fish Quay on 31st March, one was found with unsymmetrical reproductive organs. The other six were immature females with the normal pair of ovaries. The abnormal specimen has a right gonad quite similar to the ovaries of females at the same stage of maturity. It is bandlike in form, extending along the whole length of the abdominal cavity. The inner or left side is covered with smooth peritoneal epithelium (mesoarium). The greater part of the surface of the right (outer) side is raised into transverse lamellæ containing the as yet little-developed ova embedded in fattissue. For about one to two millimetres from its free edge, the organ consists of a strip of fat-tissue quite free from germinal cells, and there is a similarly constituted longitudinal fold-here and there divided into a subsidiary one-extending parallel to and about $2 \mathrm{~mm}$. from the free edge and bordering the lamellated germinal area. The ovary is $17.5 \mathrm{~cm}$. long, its greatest width $12 \mathrm{~mm}$., and the widest part of the lamellated area is about $7 \mathrm{~mm}$.

The left gonad is a sterile ovary, the transverse germinal ridges being quite absent. Along the line of attachment there is a narrow longitudinal ridge of fat-tissue, fairly well developed anteriorly, but becoming discontinuous towards the hinder end; then a narrow strip of bare peritoneal epithelium (the area which is normally covered with the egg-bearing lamellæ); and along the free edge are folds of fattissue similar to those occurring in the normal ovary.

I am indebted to Mr. J. T. Cunningham for his kindness in examining and giving his opinion upon this specimen.

It is interesting to note that this abnormal individual was the sixteenth Conger examined by me since March 14th with the object of 
obtaining a male specimen; but up to this time only females had been found. The sizes ranged from 92 to $58 \mathrm{~cm}$., ten of them being less than $76 \mathrm{~cm}$. ( $2 \mathrm{ft} .6$ inches) which is the limiting size given by Cun-

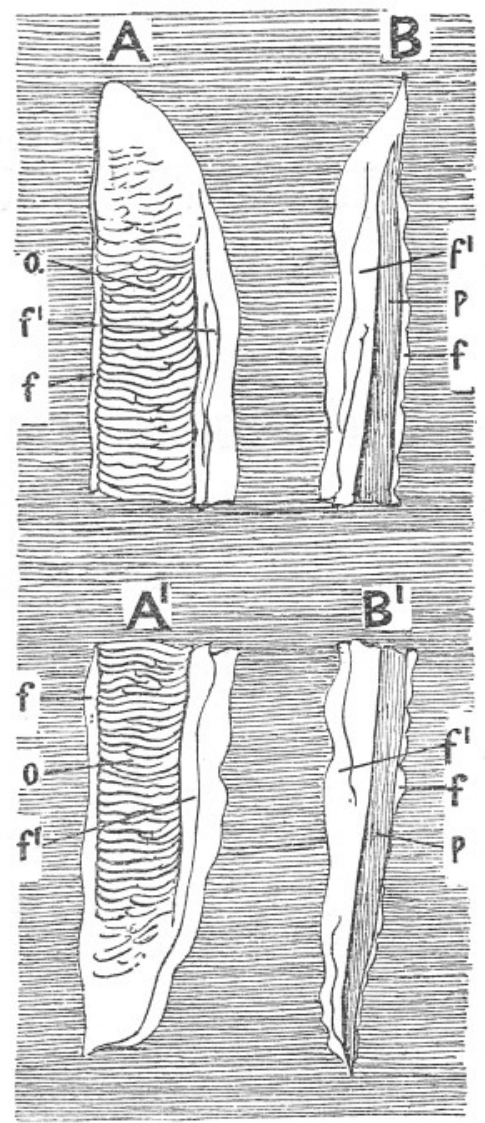

Fig. 1.-Abnormal Gonad of Conger.

$A$, anterior ; $A^{1}$, posterior end of right (normal) gonad.

$\mathrm{B}$, anterior ; $\mathrm{B}^{1}$, posterior end of left (abnormal) gonad.

o, egg-bearing lamellæ; f, fat-tissue along attachment edge

of ovary ; $\mathrm{f}^{1}$, fat-tissue along the free edge of ovary.

$\mathrm{p}$, peritoneal tissue (mesoarium).

ningham* for male Conger. Subsequently I have obtained two males, of $61 \mathrm{~cm}$. (24 inches) and $50 \mathrm{~cm}$. (20 inches) out of twenty trawlcaught Conger ranging from 77 to $50 \mathrm{~cm}$. in length.

* J. T. Cunningham, "On the Reproduction and Development of the Conger" (Journ. M.B.A., vol. ii, N.S., p. 31). 